\title{
Correction: Staufen 1 amplifies proapoptotic activation of the unfolded protein response
}

\author{
Mandi Gandelman · Warunee Dansithong · Karla P. Figueroa · Sharan Paul · Daniel R. Scoles · Stefan M. Pulst
}

Published online: 19 January 2021

(c) The Author(s), under exclusive licence to ADMC Associazione Differenziamento e Morte Cellulare 2021. This article is published with open access

Correction to: Cell Death \& Differentiation

https://doi.org/10.1038/s41418-020-0553-9

The original version of this article unfortunately contained a mistake. There was a typo in a gene name in the results of this manuscript. The gene was written as CGN2, when it should be GCN2.

Open Access This article is licensed under a Creative Commons Attribution 4.0 International License, which permits use, sharing, adaptation, distribution and reproduction in any medium or format, as long as you give appropriate credit to the original author(s) and the source, provide a link to the Creative Commons license, and indicate if changes were made. The images or other third party material in this article are included in the article's Creative Commons license, unless indicated otherwise in a credit line to the material. If material is not included in the article's Creative Commons license and your intended use is not permitted by statutory regulation or exceeds the permitted use, you will need to obtain permission directly from the copyright holder. To view a copy of this license, visit http://creativecommons. org/licenses/by/4.0/. 